\title{
ANALYSIS OF DISTANCE EDUCATION BUSINESS MODELS IN BRAZILIAN PRIVATE HIGHER EDUCATION INSTITUTIONS
}

\author{
Dr. Lidiane Campos BRITTO \\ ORCID: 0000-0002-8170-9235 \\ Universidade Municipal de Sao Caetano do Sul \\ Sao Caetano do Sul, BRASIL \\ Dr. Sergio Feliciano CRISPIM \\ ORCID: 0000-0002-4060-8315 \\ Universidade Municipal de Sao Caetano do Sul \\ Sao Caetano do Sul, BRASIL
}

Received: 12/12/2018 Accepted: 06/12/2019

\begin{abstract}
This article is based on a research whose objective was to create and analyze the undergraduate business model taxonomy in Distance Education (DE) modality at private Higher Education Institutions in Brazil. As methodological procedure, a survey was conducted from August to November 2017, with 43 Brazilian institutions and a cluster analysis. The analysis resulted in the formation of two to three groups (clusters) in each of the nine business model building blocks explored in the literature review, in a total of 24 groups. From these groupings and the analysis of each group characteristics, their taxonomic classifications were created, that is, the main objective of this work. Two distinct and recurrent business models in distance education were also identified and analyzed, based on the 43 surveyed institutions study.
\end{abstract}

Keywords: Business model. Distance education. Taxonomy.

\section{INTRODUCTION}

Since the enactment of Lei de Diretrizes e Bases da Educacao Nacional (National Education Guidelines and Foundations Law) from December 20, 1996 (LDB, 1996), Brazilian educational environment has changed dramatically. From that moment on, mergers, acquisitions and international capital infusion have increased among Brazilian private higher education institutions. As a result, large educational groups have been formed, which have, since then, developed different business models and value propositions.

Globally, there is already a lot of research and publications about distance education in relation to pedagogical models, concepts, characteristics, features and technological challenges, considering public policies and regulatory frameworks. It's noticed, however, based on an extensive literature review, that the business model theme in distance education - fully involving organizational aspects related to what, how and for whom to do it - is still little explored in a broader and deeper way, being more limited to financial and sustainability issues. Therefore, there is a theoretical gap that justifies academic research on business models in distance education, and in this sense, this research created and analyzed a taxonomy for undergraduate business models in the Distance Education modality of private higher education institutions in Brazil. It aims to strengthen, thus, a more holistic approach to DE, focusing on a management perspective, complementing the pedagogical and technological issues that have already been explored. In this context and from the management perspective, this article aims to contribute to a better understanding of distance education at a higher level in Brazil, and also to develop a methodology and generic framework that can be replicated through research on distance education in other countries, enabling comparability of business models.

In the theoretical framework, in order to demonstrate the overview of the theme from the perspective of the management area, concepts related to the business model, distance education and innovation in distance education were briefly handled and analyzed. As methodological procedure, a descriptive research 
was conducted by means of a survey, from August to November 2017, with 43 private HEIs offering distance graduation in Brazil. As research technique, we opted for the use of Cluster Analysis, also known as Segmentation Analysis or Taxonomy Analysis (Prearo, 2008).

Based on the research instrument specifically created for this study responses, two to three groups (clusters) were formed in each of the nine business model building blocks, in a total of 24 groups according to Osterwalder, Pigner and Tucci's concept (2005). Two distinct and more recurrent business models in distance education were also identified and analyzed, based on the 43 surveyed HEIs study.

\section{Theoretical Reference}

The expression business model became more broadly used from the mid-1990s (Demil \& Lecocq, 2010; Zott, Amit \& Massa, 2011) but, in spite of this subject related literature evolution there is still no consensus around it. According to Rocha (2015), the lack of clarity and consensus in the definition of such a used expression in the business literature indicates that difficulties can occur in the advancement of research on the subject, and in this sense, studies that might help to elucidate the issue are desirable.

Zott and Amit (2008) argue that technological progress has brought several opportunities for the creation of organizational arrangements between companies and their stakeholders. They also affirm that the concept of business model has been usually discussed in the technology and innovation management fields. In this way, there are two specific forms to characterize the issue. The first one states that organizations can trade ideas, concepts and innovative technologies through their business model. Second, the creation of a business model itself translates into innovation as it shapes different forms of organization, processes, and collaboration. That is, new business models not only bring consequences to technological innovations but can effectively be shaped by them (Zott $\&$ Amit, 2008).

Osterwalder et al. (2005) and Osterwalder and Pigneur (2011) argue that a business model can be decomposed and described by nine basic building blocks, which show the logic of how an organization intends to generate value. In a model, known as Canvas, these nine basic building blocks cover four major areas of a business.

In Table 1 the nine building blocks are described according to their attachment to one of the four areas proposed by Osterwalder et al. (2005).

Table 1. Nine Business Model Building Blocks

\begin{tabular}{|c|c|c|}
\hline Pillar & Business Model Building Block & Description \\
\hline Product & Value Proposition & $\begin{array}{l}\text { Gives an overall view of a company's bundle of products } \\
\text { and services. }\end{array}$ \\
\hline \multirow{3}{*}{ Customer Interface } & Target Customer & $\begin{array}{l}\text { Describes the segments of customers a company wants } \\
\text { to offer value to. }\end{array}$ \\
\hline & Distribution Channel & $\begin{array}{l}\text { Describes the various means of the company to get in } \\
\text { touch with its customers. }\end{array}$ \\
\hline & Relationship & $\begin{array}{l}\text { Explains the kind of links a company establishes between } \\
\text { itself and its different customer segments. }\end{array}$ \\
\hline \multirow{3}{*}{$\begin{array}{l}\text { Infrastructure } \\
\text { Management }\end{array}$} & Value Configuration & Describes the arrangement of activities and resources. \\
\hline & Core Competency & $\begin{array}{l}\text { Outlines the competencies necessary to execute the } \\
\text { company's business model. }\end{array}$ \\
\hline & Partner Network & $\begin{array}{l}\text { Portrays the network of cooperative agreements with } \\
\text { other companies necessary to efficiently offer and } \\
\text { commercialize value. }\end{array}$ \\
\hline \multirow{2}{*}{ Financial Aspects } & Cost Structure & $\begin{array}{l}\text { Sums up the monetary consequences of the means } \\
\text { employed in the business model. }\end{array}$ \\
\hline & Revenue Model & $\begin{array}{l}\text { Describes the way a company makes money through a } \\
\text { variety of revenue flows. }\end{array}$ \\
\hline
\end{tabular}

Note: OSTERWALDER, A.; PIGNEUR, Y.; TUCCI, C, L. Clarifying Business Models: Origins, Present, and Future of the Concept. Communications of AIS, Volume 15, Article. May 2005, p. 18. 
For conceptual purposes, according to the study done by the authors presented here, one can understand business model as: representation of the main components (decision areas) and elements (decision variables) necessary for an organization to generate and capture value in order to become competitive and sustainable over time. Thus, all organizations possess the components and elements that make up their business model, but the principle is that their structured explicitness in a framework - called generically as a business model contributes to the alignment of its parts and to greater competitiveness in the delivery of value to customers - and value capture for the company.

\section{Distance Education}

Distance education (DE) is characterized by the Brazilian Association of Distance Education (ABED) as the modality of education in which teaching and learning activities are developed mostly without students and teachers being present at the same place at the same time (ABED, 2015).

The concept of distance education in Brazil is officially established by Decree number 5.622 of December 19, 2005 (BRAZIL, 2015). The text defines that the distance education is the:

Educational modality in which the didactic-pedagogical mediation in the teaching and learning processes occurs with the use of media and information and communication technologies, with students and teachers developing educational activities in different places or times.

Moore and Kearsley (2013) point out that the overarching idea of distance education is simple: teacher and students in different places all the time or for the most part, at the time they teach and learn, interacting by means of some form of communication technology.

Mantovani, Gouvea and Tamashiro (2015) endorse that distance education enables students to study remotely, without the need for constant physical presence, wherever they may be. Cassunde and Cassunde Jr (2012) also argue that besides the advantage of distance education serving a large number of students, in the same space of time and in different places, it still has cost benefits and flexible hours for students.

\section{The numbers of Distance Education in Brazil}

According to the publication Map of Higher Education in Brazil 2017, by Higher Education Maintainers Union (SEMESP), enrollment numbers in the $2009-2015$ DE under graduation increased by $66 \%$, or $8.8 \%$ per year, considering an increase of $90 \%$ in private institutions and $26 \%$ decrease in public ones (SEMESP, 2017).

In the Statistical Synthesis of Higher Education 2016 (INEP, 2017), the indicators are even more expressive. Considering private and public HEIs, the number of undergraduate courses in DE nationwide in 2016 was 1,662 , or $11.5 \%$ of the total undergraduate courses, with 230,717 graduates, or $36.2 \%$ of the total. Yet in 2016, there were 1,494,418 students enrolled in DE courses, or $33.2 \%$ of all enrollments in higher education.

Based on both modalities evolution (face-to-face and on-line), DE offers great possibilities of being significantly responsible for the expansion of undergraduate enrollments in Brazil over the next few years, aiming at achieving Goal 12 of the National Education Plan, Ministry of Education (MEC) and Teaching Systems Articulation Secretary (SASE), 2014.

With regard to business model innovation studies at the HEIs that deal with distance education, studies by Christensen (2012) are reference. According to the author, distance education is a disruptive, or breakthrough innovation.

According to Christensen, Horn and Johnson (2012), disruptive innovation turns affordable/functional breakthrough products/services, using simpler applications, and attracting what the authors call "nonconsumers".

DE was initially seen in Brazil as a cheaper, inferior service oriented to an audience that did not have access to face-to-face education, mainly due to financial limitations or lack of time. Today, DE has gained new formats and, in terms of quality and enrollment, as already discussed, is equating itself to face-to-face education. It is evolving incrementally and attending to more demanding audiences than those attended in the initial phase. 


\section{METHODOLOGY PROCEDURES}

Based on this study general objective (to create and analyze the undergraduate business model taxonomy in Distance Education modality at private Higher Education Institutions in Brazil) we chose a descriptive research based on field survey, using a structured questionnaire as data collection instrument. Although this is a descriptive research from its method point of view, due to sample limitation (non-probabilistic), it also presents characteristics of an exploratory work.

The research began with the development of a data collection instrument that detailed the specific factors at higher education distance education segment for the nine generic components business models. This effort resulted in a generic business model with the specifics of distance education. The development took place by means of a comprehensive international bibliographical review and five semi-structured interviews with specialists in distance education. The survey was initially carried out in a universe of 130 HEIs offering DE undergraduate courses in Brazil, based on Higher Distance Education Regulation General Coordination (COREAD) list by the Ministry of Education (MEC) in Brazil, based on E-MEC system, available in internet, and open to public in general. After direct contact with the HEIs, there were 117 Higher Education Institutions that offered under graduation DE modality in Brazil. From these 117 HEIs, some (a small but important percentage in a restricted universe) said they would not respond to the questionnaire. The reasons were different: no authorization from the principals, the HEI wasn't used to respond to any type of research, or because the necessary information was, in fact, strategies and could not be provided. Out of 117 qualified HEIs to respond, 43 did so in a valid way, characterizing a research with a non-probabilistic sample. Respondent institutions' name is not public and reported data were treated in a grouped manner, not allowing the individual identification of the interviewees, nor the HEI's.

Since it is a quantitative data analysis proposed for private HEIs as a means of identifying business models, we opted for the use of Cluster Analysis, also known as Segmentation Analysis or Taxonomy Analysis (Prearo, 2008; Gouvea, Prearo \& Romeiro, 2013).

According to Garson (2007) as quoted in Prearo (2008, p.26), the hierarchical method is best suited for samples smaller than 250 in a cluster analysis as in this research. Hair et al. (2009, p. 439), in turn, state that "the sample size issue in cluster analysis is not related to any problems of statistical inference." That is, for the authors, the sample should be enough to grant its representativeness in the study. This was the main reason why we chose to run a cluster analysis for each of the nine components, instead of for the whole questionnaire. In the universe of 117 Higher Education Institutions, a sample of 43 was selected. The used questionnaire is extensive and has many variables in its entirety, which could cause research biases and bring atypical observations problems.

According to criteria suggested by Hair et al. (2009), it is necessary to adopt a distance measure in cluster analysis so that the technique can make sense. The chosen measurement was Euclidean distance, generally used in cluster analysis and widely used to measure the similarity between two objects. Basically, it is the linear distance between two graphed objects (Hair et al., 2009, p. 428).

Regarding the clustering algorithms, what best fits this work for its characteristics is the mean binding method, as Hair et al. (2009) calls it. According to the authors, "this algorithm does not depend on extreme values (closer or farther pairs). Similarity is based on all elements from the aggregates and does not have a single pair of extreme members, being, thus, less affected by atypical observations" (Hair et al., 2009, p. 451).

For Lambert (2017), business models are abstract and complex concepts on which understanding can be improved by the development of a general classification scheme. According to the author, the recognition of similarities and differences between business models and the development of categories for business models are fundamental to the subject research. Thus, an effective classification scheme organizes objects according to their place within the problem domain and represents relationships between them. For Lambert (2017) there is an important distinction in the classification schemes between typologies and taxonomies. The typologies are the product of deductive research, in this way, it is the researcher that conceptuates the relevant types to the research. Taxonomic research, however, involves the identification of a large number of variables in which data were collected. These variables determination should be based on the existing domain knowledge that was generated through deductive research. Data are analyzed using multivariate analysis (cluster, for example) to identify natural groups (classes) (Lambert, 2017). 


\section{RESULTS PRESENTATION}

The questionnaire specifically related to the business model has 52 questions, divided into nine blocks. Each of these blocks corresponds to a generic business model building block (Ostewalder; Pigneur, 2011). The construction of each question refers to two topics: adequacy to the object of study and attempt to adapt it to the used statistical technique. Questions were formulated so as not to arouse doubts and we, therefore, sought to develop a questionnaire, at the same time, "easy" to answer, and long and deep enough in what it was proposed. Equity in the number of questions in the nine components of a business model was not sought. The aim was to work with Distance Education adequacy for each of the proposed variables. In formulating questions, the issue was what really can differentiate business models in relation to each of the components, considering that the research was conducted in private HEIs offering undergraduate degrees in Distance Education.

The components used in the questionnaire are: Target Customer, Value Proposition, Distribution Channel, Relationship, Value Configuration, Core Competency, Partner Network, Cost Structure and Revenue Model (Osterwalder, Pigneur \& Tucci, 2005; Osterwalder \& Pigneur, 2011).

It is important to highlight that, following Hair et al.'s recommendation (2009), it was observed that the simultaneous processing of all variables, with no building block discrimination, could produce divergent results, once it is a small universe (117 HEIs) in relation to the variables and respondent numbers ( $43 \mathrm{HEIs}$ ). Thus, in order to avoid compromising the analysis, the questionnaire was processed by building block. That is, we examined the formed clusters in each of the nine building blocks of a generic business model separately.

Once the questionnaire has many different variables and scales between questions, including the same component, justified to discard some variables for cluster analysis, and use them later in a descriptive one. This action tends to decrease the possibility of multicollinearity in cluster analysis, since, according to Hair et al. (2009, p. 447): "Multicollinearity acts as a process not visible to the observer but that affects analysis. For this reason, the researcher is encouraged to examine clustering variables for substantive multicollinearity." Thus, according to the authors, equalizing the number of variables is a way of solving this problem, or alternatively balancing the number of factors to substantially decrease it.

In order to measure the research instrument reliability in this article, Cronbach's Alpha test was used, which, according to Hair et al., (2009, p. 100) is "the reliability measure ranging from 0 to 1 , being values from 0.60 to 0.70 considered the lower limit of acceptability".

The following table is the result of the questionnaire reliability test based on the use of Cronbach's Alpha.

Table 2. Questionnaire reliability test

RELIABILITY TEST

\begin{tabular}{lcc}
\hline BUSINESS MODEL COMPONENTS & CRONBACH'S ALPHA & RELIABILITY \\
\hline Target Customer &, 025 & Low \\
Value Propostion &, 846 & High \\
Distribution Channel &, 904 & High \\
Relationship &, 220 & Low \\
Value Configuration &, 872 & High \\
Core Competency &,- 224 & Zero \\
Partner Network &, 746 & High \\
Cost Structure &, 844 & High \\
Revenue Model &, 890 & High \\
\hline
\end{tabular}

Note: Elaborated by the authors based on field research

Six of nine components had high reliability, and despite two components had low reliability (Target Customer and Relationship), and one of the components, Core Competency, negative reliability (that is, unreliable), all questionnaire variables, relative to the nine components of the business model, were previously raised 
through semi-structured interviews with Distance Education professionals and a long theoretical framework (Britto, 2018). However, according to Da Hora, Monteiro and Arica (2010, p. 85), although scientific literature on the application of the coefficient in the various areas of knowledge is broad and comprehensive, there is still no consensus among researchers about the interpretation of the reliability of a questionnaire obtained from the value. Thus, although Cronbach's Alpha is not favorable in three components, specifically in this research, the results are valid because the construction of the questionnaire was based on valid sources.

Table 3 below, presents the Taxonomic Classification synthesis for the formed groupings and a brief description of each one of them. It describes the nine building blocks of a business model and its groupings considering the very specific and homogeneous characteristics within distance education, gathered through cluster analysis. The table also includes the numbers of HEI belonging to each formed group along with a brief description that bases the taxonomic classification.

Some respondents, as expected in a questionnaire with high number of variables, failed to answer some questions (missing values), what hasn't compromised the research results. HEIs that failed to answer an expressive number of questions that could compromise the results were ruled out from the analysis and are called "excluded" (X). In addition, some HEIs could not be grouped into some specific building blocks, that is, they are different from all others in that building block. In this sense, some of them, as HEI 1, por example, appear isolated from the others in some formed groupings. These institutions that have not been grouped are called "solitary" (SO).

Table 3. Groups Taxonomic Classification Synthesis

\begin{tabular}{|c|c|c|c|c|}
\hline $\begin{array}{l}\text { Business Model } \\
\text { Building Block }\end{array}$ & $\begin{array}{l}\text { Formed groups } \\
\text { (clusters) }\end{array}$ & Number of HEIs & $\begin{array}{l}\text { Taxonomic } \\
\text { Classification }\end{array}$ & Brief Group Description \\
\hline \multirow{5}{*}{$\begin{array}{c}\text { TARGET } \\
\text { CUSTOMER }\end{array}$} & G1 & 21 & Traditional & $\begin{array}{l}\text { High number of students who are } \\
\text { in their first under graduation, less } \\
\text { experienced and that are within } 20 \\
\text { to } 29 \text { years old. }\end{array}$ \\
\hline & G2 & 11 & Professional & $\begin{array}{l}\text { Older students, with higher } \\
\text { income, and more experienced. } \\
\text { Students who, in general, have a } \\
\text { previous academic experience. }\end{array}$ \\
\hline & G3 & 7 & Intermediate & $\begin{array}{l}\text { Through obtained information, } \\
\text { the HEls belonging to this group } \\
\text { do not have a specific customer } \\
\text { segment. There are students with } \\
\text { profiles from both groups } 1 \text { and } 2 \text {. }\end{array}$ \\
\hline & Solitaries (SO) & 1 & ----- & ---- \\
\hline & Excluded $(X)$ & 3 & ----- & $\begin{array}{l}---- \\
\end{array}$ \\
\hline \multirow{4}{*}{$\begin{array}{c}\text { VALUE } \\
\text { PROPOSITION }\end{array}$} & G4 & 23 & Standard & $\begin{array}{l}\text { Offers an average proposal. HEI } \\
\text { is known but not admittedly } \\
\text { recognized as a strong high- } \\
\text { quality institution, and its students } \\
\text { still face more difficulties in } \\
\text { understanding the distance } \\
\text { education concept. }\end{array}$ \\
\hline & G5 & 15 & Superior & $\begin{array}{l}\text { An admittedly strong brand in the } \\
\text { market, offering higher quality } \\
\text { proposal compared to group } \\
\text { 1, a more personalized matrix } \\
\text { and highly qualified faculty, its } \\
\text { students face less difficulties } \\
\text { in understanding distance } \\
\text { education concept and consider } \\
\text { indispensable time flexibility to } \\
\text { study. }\end{array}$ \\
\hline & Solitaries (SO) & 3 & ----- & $\begin{array}{l}---- \\
\end{array}$ \\
\hline & Excluded (X) & 2 & ----- & ----- \\
\hline
\end{tabular}




\begin{tabular}{|c|c|c|c|c|}
\hline & G6 & 30 & $\begin{array}{l}\text { Multiple } \\
\text { Channels }\end{array}$ & $\begin{array}{l}\text { It attaches great importance } \\
\text { to a variety of means used for } \\
\text { administrative and pedagogical } \\
\text { matters, that is, it offers various } \\
\text { forms of contact with students. }\end{array}$ \\
\hline & G7 & 5 & $\begin{array}{l}\text { Distinct or } \\
\text { Restrictive } \\
\text { Channels }\end{array}$ & $\begin{array}{l}\text { It attaches great importance } \\
\text { to the VLE for the resolution of } \\
\text { administrative and pedagogical } \\
\text { situations relating students while } \\
\text { low importance to other means. }\end{array}$ \\
\hline & Solitaries (SO) & 1 & ----- & $\begin{array}{l}+--- \\
\end{array}$ \\
\hline $\begin{array}{c}\text { DISTRIBUTION } \\
\text { CHANNEL }\end{array}$ & Excluded (X) & 7 & ----- & ----- \\
\hline \multirow{5}{*}{ RELATIONSHIP } & G8 & 19 & $\begin{array}{l}\text { DE exclusive } \\
\text { relationship with } \\
\text { media variety }\end{array}$ & $\begin{array}{c}\text { Provides exclusive relationship } \\
\text { with DE students through multiple } \\
\text { channels / media. }\end{array}$ \\
\hline & G9 & 8 & $\begin{array}{l}\quad \text { Shared } \\
\text { relationship } \\
\text { between on-line } \\
\text { and face-to-face } \\
\text { education } \\
\end{array}$ & $\begin{array}{l}\text { There is no exclusive relationship } \\
\text { for DE students. The channels / } \\
\text { media are shared with students } \\
\text { from face-to-face modality. }\end{array}$ \\
\hline & G10 & 16 & $\begin{array}{l}\text { DE exclusive } \\
\text { relationship } \\
\text { using traditional } \\
\text { means }\end{array}$ & $\begin{array}{l}\text { It offers exclusivity in the } \\
\text { relationship with DE students, but } \\
\text { in a restricted way, without variety } \\
\text { of means / channels. }\end{array}$ \\
\hline & Solitaries (SO) & ----- & ----- & ----- \\
\hline & Excluded (X) & ---- & ----- & ----- \\
\hline \multirow{5}{*}{$\begin{array}{c}\text { VALUE } \\
\text { CONFIGURATION }\end{array}$} & G11 & 19 & Intermediate & $\begin{array}{l}\text { It is a hybrid between groups } 2 \\
\text { and } 3 \text {. Offers innovative but also } \\
\text { conventional core DE activities. }\end{array}$ \\
\hline & G12 & 13 & Traditional & $\begin{array}{l}\text { It is more conventional and } \\
\text { standard in offering core DE } \\
\text { activities. }\end{array}$ \\
\hline & G13 & 7 & Innovative & $\begin{array}{l}\text { It is bolder, evading DE standard } \\
\text { propositions while offering core } \\
\text { activities for the segment. }\end{array}$ \\
\hline & Solitaries (SO) & 1 & ---- & ---- \\
\hline & Excluidas (X) & 3 & ----- & ----- \\
\hline \multirow{6}{*}{$\begin{array}{c}\text { CORE } \\
\text { COMPETENCY }\end{array}$} & G14 & 36 & Standard & $\begin{array}{l}\text { It has a HEI profile within standard } \\
\text { features, with no competitive } \\
\text { advantage differential sources. }\end{array}$ \\
\hline & G15 & 3 & & $\begin{array}{l}\text { It has a more focused profile on } \\
\text { Core DE activities, although with } \\
\text { resources similar to Group } 1 .\end{array}$ \\
\hline & \multicolumn{4}{|c|}{ Focused } \\
\hline & G16 & 2 & Uncertain & $\begin{array}{c}\text { HEls in this group failed to answer } \\
\text { some questions. Therefore, the } \\
\text { result is inconclusive. }\end{array}$ \\
\hline & Solitaries (SO) & 2 & ----- & $\begin{array}{ll}---- \\
\end{array}$ \\
\hline & Excluded (X) & ----- & ----- & ----- \\
\hline
\end{tabular}




\begin{tabular}{|c|c|c|c|c|}
\hline \multirow{4}{*}{$\begin{array}{l}\text { PARTNER } \\
\text { NETWORK }\end{array}$} & G17 & 38 & $\begin{array}{l}\text { More open to } \\
\text { partnerships }\end{array}$ & $\begin{array}{l}\text { It tends to share more resources } \\
\text { internally (on-line versus face-to- } \\
\text { face) and among the HEls from its } \\
\text { group. }\end{array}$ \\
\hline & G18 & 4 & $\begin{array}{l}\text { Less open to } \\
\text { partnerships }\end{array}$ & $\begin{array}{l}\text { It tends to share less resources } \\
\text { internally or avoids doing it } \\
\text { (on-line versus face-to-face) and } \\
\text { among the HEls from its group. }\end{array}$ \\
\hline & $\begin{array}{c}\text { Solitaries } \\
\text { (SO) }\end{array}$ & ----- & ---- & ---- \\
\hline & Excluded (X) & 1 & +--- & ----- \\
\hline \multirow{5}{*}{$\begin{array}{l}\text { COST } \\
\text { STRUCTURE }\end{array}$} & G19 & 4 & $\begin{array}{l}\text { Group excluded } \\
\text { due to lack } \\
\text { of active } \\
\text { participation }\end{array}$ & $\begin{array}{l}\text { Group excluded due to lack of } \\
\text { respondents' participation. }\end{array}$ \\
\hline & G20 & 2 & Cost leadership & $\begin{array}{l}\text { Cost structure that tends to be } \\
\text { lean, with low added value. }\end{array}$ \\
\hline & G21 & 37 & Insight & $\begin{array}{c}\text { Average cost structure with } \\
\text { medium to high added value in } \\
\text { specific segment, with resources } \\
\text { aimed at serving it. }\end{array}$ \\
\hline & $\begin{array}{c}\text { Solitaries } \\
\text { (SO) }\end{array}$ & ----- & ----- & ----- \\
\hline & Excluded (X) & ----- & ---- & ---- \\
\hline \multirow[t]{5}{*}{$\begin{array}{l}\text { REVENUE } \\
\text { MODEL }\end{array}$} & G22 & 10 & $\begin{array}{l}\text { Monthly-based } \\
\text { with restrictive } \\
\text { discount policy }\end{array}$ & $\begin{array}{l}\text { Monthly-based student payment. } \\
\text { There is discount policy, but it is } \\
\text { not expressively. }\end{array}$ \\
\hline & G23 & 9 & $\begin{array}{c}\text { Monthly-based } \\
\text { with no discount } \\
\text { policy }\end{array}$ & $\begin{array}{l}\text { Monthly-based student payment. } \\
\text { There is no discount policy. }\end{array}$ \\
\hline & G24 & 24 & $\begin{array}{c}\text { Monthly- } \\
\text { based with } \\
\text { considerable } \\
\text { discount policy }\end{array}$ & $\begin{array}{l}\text { Monthly-based payment. The HEls } \\
\text { have a strong wide range discount } \\
\text { policy. }\end{array}$ \\
\hline & $\begin{array}{l}\text { Solitarias } \\
\text { (SO) }\end{array}$ & ----- & ---- & ---- \\
\hline & Excluidas (X) & ----- & ---- & ----- \\
\hline
\end{tabular}

Note: Elaborated by the authors based on field research

\section{Identification of Sampled and Most Recurring Business Models}

The business models for the studied institutions can be defined by their generic building blocks combination with their respective 24 groups (clusters) formed by the cluster analysis performed in this research.

There is a possibility of 5,832 business models, which correspond to the statistical combinations of the 9 building blocks and their respective groups. However, as the sample is made up of 43 higher education institutions, the possibilities are reduced to 43 different business models. Table 4 represents these 43 business models for the surveyed HEIs, or combinations of groups based on cluster analysis. 


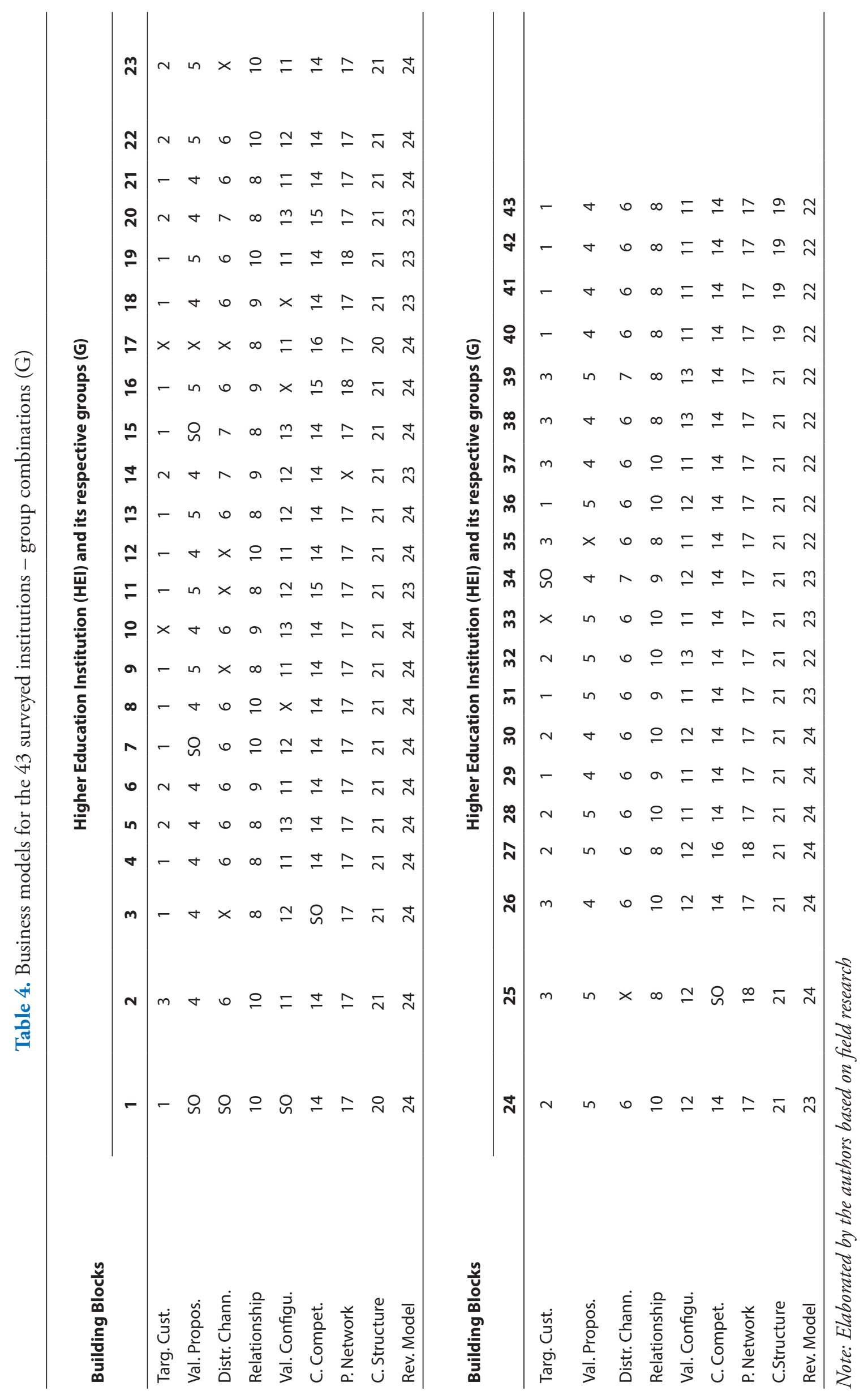


Among the 43 possible combinations, we identified only two equal business models adopted by more than one HEI. The first business model is that of HEIs 40, 41, 42 and 43 that for each of the 9 business model building blocks have the same groups, according to table 5. Probably this is due to the fact that the four institutions belong to the same educational group. Thus, these four institutions focus on the same target customer and value proposition, use the same distribution channels, have the same type of customer relationship, use the same value configurations, perform similar core competencies, create the same partnership network with identical cost structures and having similar revenue sources.

Table 5. Business Model for HEIs 40, 41, 42 and 43

\begin{tabular}{|c|c|c|c|c|c|c|}
\hline \multirow[b]{2}{*}{ Building Blocks } & \multicolumn{6}{|c|}{ Higher Education Institutions (HEls) } \\
\hline & 40 & 41 & 42 & 43 & $\begin{array}{l}\text { Taxonomic } \\
\text { Classification }\end{array}$ & Description \\
\hline Target Customer & G1 & G1 & G1 & G1 & Traditional & $\begin{array}{l}\text { High number of students who are } \\
\text { in their first under graduation, less } \\
\text { experienced and that are within } 20 \text { to } \\
29 \text { years old. }\end{array}$ \\
\hline Value Proposition & G4 & G4 & G4 & G4 & Standard & $\begin{array}{l}\text { Offers an average proposal. HEl is } \\
\text { known but not admittedly recognized } \\
\text { as a strong high-quality institution, and } \\
\text { its students still face more difficulties in } \\
\text { understanding the distance education } \\
\text { concept. }\end{array}$ \\
\hline Distribution Channel & G6 & G6 & G6 & G6 & Multiple Channels & $\begin{array}{l}\text { It attaches great importance } \\
\text { to a variety of means used for } \\
\text { administrative and pedagogical } \\
\text { matters, that is, it offers various forms } \\
\text { of contact with students. }\end{array}$ \\
\hline Relationship & G8 & G8 & G8 & G8 & $\begin{array}{l}\text { DE exclusive } \\
\text { relationship with } \\
\text { media variety }\end{array}$ & $\begin{array}{l}\text { Provides exclusive relationship with DE } \\
\text { students through multiple } \\
\text { channels / media. }\end{array}$ \\
\hline Value Configuration & G11 & G11 & G11 & G11 & Intermediate & $\begin{array}{c}\text { It is a hybrid between groups } 2 \text { and } 3 \text {. } \\
\text { Offers innovative but also conventional } \\
\text { core DE activities. }\end{array}$ \\
\hline Core Competency & G14 & G14 & G14 & G14 & Standard & $\begin{array}{l}\text { It has a HEI profile within standard } \\
\text { features, with no competitive } \\
\text { advantage differential sources. }\end{array}$ \\
\hline Partner Network & G17 & G17 & G17 & G17 & $\begin{array}{l}\text { More open to } \\
\text { partnerships }\end{array}$ & $\begin{array}{l}\text { It tends to share more resources } \\
\text { internally (on-line versus face-to-face) } \\
\text { and among the HEls from its group. }\end{array}$ \\
\hline Cost Structure & G19 & G19 & G19 & G19 & $\begin{array}{l}\text { Group excluded } \\
\text { due to lack of active } \\
\text { participation }\end{array}$ & $\begin{array}{l}\text { Group excluded due to lack of } \\
\text { respondents' participation. }\end{array}$ \\
\hline Revenue Model & $\mathrm{G} 22$ & G22 & $\mathrm{G} 22$ & $\mathrm{G} 22$ & $\begin{array}{l}\text { Monthly-based with } \\
\text { restrictive discount } \\
\text { policy }\end{array}$ & $\begin{array}{l}\text { Monthly-based student payment. } \\
\text { There is discount policy, but it is not } \\
\text { expressively. }\end{array}$ \\
\hline
\end{tabular}

Note: Elaborated by the authors based on field research

The second business model is that of HEIs 4 and 21, which are also identical in the composition of the building blocks, according to table 6. They differ from HEIs 40, 41, 42 and 43 only in the cost structure and revenue models. That is, they have seven components with equal combinations to the business model for HEIs 40, 41, 42 and 43. 
Table 6. Identical Business Model for HEIs 4 and 21

\begin{tabular}{|c|c|c|c|c|}
\hline \multirow[b]{2}{*}{ Building Blocks } & \multicolumn{4}{|c|}{ Higher Education Institutions (HEls) } \\
\hline & 4 & 21 & $\begin{array}{l}\text { Taxonomic } \\
\text { Classification }\end{array}$ & Description \\
\hline Target Customer & G1 & G1 & Traditional & $\begin{array}{l}\text { High number of students who are in their } \\
\text { first under graduation, less experienced and } \\
\text { that are within } 20 \text { to } 29 \text { years old. }\end{array}$ \\
\hline Value Proposition & G4 & G4 & Standard & $\begin{array}{l}\text { Offers an average proposal. HEl is known } \\
\text { but not admittedly recognized as a strong } \\
\text { high-quality institution, and its students still } \\
\text { face more difficulties in understanding the } \\
\text { distance education concept. }\end{array}$ \\
\hline Distribution Channel & G6 & G6 & Multiple Channels & $\begin{array}{l}\text { It attaches great importance to a variety } \\
\text { of means used for administrative and } \\
\text { pedagogical matters, that is, it offers various } \\
\text { forms of contact with students. }\end{array}$ \\
\hline Relationship & G8 & G8 & $\begin{array}{l}\text { DE exclusive relationship } \\
\text { with media variety }\end{array}$ & $\begin{array}{c}\text { Provides exclusive relationship with DE } \\
\text { students through multiple } \\
\text { channels / media. }\end{array}$ \\
\hline Value Configuration & G11 & G11 & Intermediate & $\begin{array}{l}\text { It is a hybrid between groups } 2 \text { and } 3 \text {. Offers } \\
\text { innovative but also conventional core DE } \\
\text { activities. }\end{array}$ \\
\hline Core Competency & G14 & G14 & Standard & $\begin{array}{c}\text { It has a HEl profile within standard features, } \\
\text { with no competitive advantage differential } \\
\text { sources. }\end{array}$ \\
\hline Partner Network & G17 & G17 & $\begin{array}{l}\text { More open to } \\
\text { partnerships }\end{array}$ & $\begin{array}{l}\text { It tends to share more resources internally } \\
\text { (on-line versus face-to-face) and among the } \\
\text { HEls from its group. }\end{array}$ \\
\hline Cost Structure & G21 & G21 & Insight & $\begin{array}{l}\text { Average cost structure with medium to high } \\
\text { added value in a specific segment, with } \\
\text { resources aimed at serving it. }\end{array}$ \\
\hline Revenue Model & G24 & $\mathrm{G} 24$ & $\begin{array}{l}\text { Monthly-based with } \\
\text { considerable discount } \\
\text { policy }\end{array}$ & $\begin{array}{l}\text { Monthly-based payment. The HEls have a } \\
\text { strong wide range discount policy. }\end{array}$ \\
\hline
\end{tabular}

Note: Elaborated by the authors based on field research

Excluding the institutions that have the two most recurring business models as described above, all others have business models with less than 9 equal building blocks. For instance, from business model analysis for HEIs 4 and 21, it is possible to identify other similar configurations in the researched institutions. This is the case of HEIs 8, 12, 18 and 29 described in table 7. HEI 29, for example, has the same pattern as HEIs 4 and 21. It is the same for 8 groups, but differs in relationship. HEI 8 has 7 coincident building blocks with those of HEIs 4 and 21, differing in relationship and absence in value configuration. HEI 12 has 7 equal building blocks, differing in distribution channel and relationship. HEI 18, in turn has only 6 equal business model building blocks to those of HEIs 4 and 21 .

Table 7, below, summarizes both the most recurring and the least frequent business models. 
Table 7. Business Models for HEIs 8, 12, 18 and 29

\begin{tabular}{|c|c|c|c|c|c|c|c|c|}
\hline \multirow[b]{2}{*}{ Building Blocks } & \multicolumn{8}{|c|}{ Higher Education Institutions (HEls) } \\
\hline & 29 & Description & 8 & $\begin{array}{l}\text { Taxonomic } \\
\text { Classification }\end{array}$ & 12 & $\begin{array}{l}\text { Taxonomic } \\
\text { Classification }\end{array}$ & 18 & $\begin{array}{l}\text { Taxonomic } \\
\text { Classification }\end{array}$ \\
\hline Target Customer & G1 & Traditional & G1 & Traditional & G1 & Traditional & G1 & Traditional \\
\hline $\begin{array}{c}\text { Value } \\
\text { Proposition }\end{array}$ & G4 & Standard & G4 & Standard & G4 & Standard & G4 & Standard \\
\hline $\begin{array}{l}\text { Distribution } \\
\text { Channel }\end{array}$ & G6 & $\begin{array}{l}\text { Multiple } \\
\text { Channels }\end{array}$ & G6 & $\begin{array}{l}\text { Multiple } \\
\text { Channels }\end{array}$ & $x$ & ---- & G6 & $\begin{array}{l}\text { Multiple } \\
\text { Channels }\end{array}$ \\
\hline Relationship & G9 & $\begin{array}{l}\text { Shared } \\
\text { relationship } \\
\text { between on-line } \\
\text { and face-to-face } \\
\text { education }\end{array}$ & G10 & $\begin{array}{l}\text { DE exclusive } \\
\text { relationship } \\
\text { using traditional } \\
\text { means }\end{array}$ & G10 & $\begin{array}{l}\text { DE exclusive } \\
\text { relationship } \\
\text { using traditional } \\
\text { means }\end{array}$ & G9 & $\begin{array}{c}\text { Shared } \\
\text { relationship } \\
\text { between on-line } \\
\text { and face-to-face } \\
\text { education }\end{array}$ \\
\hline $\begin{array}{c}\text { Value } \\
\text { Configuration }\end{array}$ & G11 & Intermediate & $\mathrm{x}$ & ------ & G11 & Intermediate & $x$ & ----- \\
\hline $\begin{array}{c}\text { Core } \\
\text { Competency }\end{array}$ & G14 & Standard & G14 & Standard & G14 & Standard & G14 & Standard \\
\hline Partner Network & G17 & $\begin{array}{l}\text { More open to } \\
\text { partnerships }\end{array}$ & G17 & $\begin{array}{l}\text { More open to } \\
\text { partnerships }\end{array}$ & G17 & $\begin{array}{l}\text { More open to } \\
\text { partnerships }\end{array}$ & G17 & $\begin{array}{l}\text { More open to } \\
\text { partnerships }\end{array}$ \\
\hline Cost Structure & G21 & Insight & G21 & Insight & G21 & Insight & G21 & Insight \\
\hline Revenue Model & G24 & $\begin{array}{c}\text { Monthly- } \\
\text { based with } \\
\text { considerable } \\
\text { discount policy }\end{array}$ & G24 & $\begin{array}{c}\text { Monthly- } \\
\text { based with } \\
\text { considerable } \\
\text { discount policy }\end{array}$ & G24 & $\begin{array}{c}\text { Monthly- } \\
\text { based with } \\
\text { considerable } \\
\text { discount policy }\end{array}$ & G23 & $\begin{array}{l}\text { Monthly-based } \\
\text { with no discount } \\
\text { policy }\end{array}$ \\
\hline
\end{tabular}

Note: Elaborated by the authors based on field research

Christensen and Eyring (2014), in "A Universidade Inovadora" (The Innovative University), explain that higher education institutions need to revitalize faster than they are actually doing to compete sustainably. However, it is clear that, in the studied samples, although researched institutions have differences in their business models, similarities are more expressive. This is even more evident when one realizes that out of 43 studied institutions, in 21 of them, at least 5 of the 9 components of their business models follow the same taxonomic classification. That is, although private higher education institutions segment in Brazil is experiencing great expansion and appreciation, particularly since 2005, these institutions are not yet characterized by intense innovation in their essence, that is, a reasonable business model commoditization still prevails in them. Innovation seems to be restricted to the disruption granted by new technologies in terms of attendance than to the multiple possibilities of business models.

Breakthrough innovation, according to Christensen (2012, p. 14), enables significant cost reduction of products or services, the development of new markets and the access of new hitherto marginalized consumers. Rupture business models in turn, tend to a natural process of incremental development through which they would be liable to differentiate over time. This research suggests thus, that distance education business models in Brazil are still in an early evolutionary phase, in which the major differential is the issue of virtual access to education at a relatively lower cost, with no qualitative advance, while, in this sense, there was probably even a setback. It is plausible to suppose that there will be an incremental evolution of business models at distance learning, characterized by greater diversity in terms of audience segmentation, value propositions and organization, with great prospect of qualitative improvement of the teaching and learning processes.

\section{CONCLUSION}

Business model concept is well explored in academic research, but in general the approaches occur at the level of generic models, identifying a theoretical gap and the need for business model research in sectors and more delimited market segments, aiming at making the concept more functional from an analytical 
and operational perspective. This is the case of distance education in higher education. Initially considered as a disruptive innovation, distance education has been moving towards a better-quality concept along with lower costs as information and communication technologies (ICT) evolve, becoming a recurrent modality adopted by HEIs and, increasingly assimilated by society.

This research purpose was to create and analyze the undergraduate business model taxonomy in Distance Education modality at private Higher Education Institutions in Brazil. To do so, we initially sought to know what a business model was in its generic conception, and more specifically, to explore the shaping of business models in the well-defined field of DE within higher education in Brazil.

In this sense, the research began with the development of a data collection instrument that detailed the specific factors at higher education DE segment for the nine generic components business models. The effort came up with a generic business model with the specifics of Distance Education. This development took place by means of a comprehensive international bibliographical review and five semi-structured interviews with specialists in distance education. Making use of a survey with 43 private higher education institutions in Brazil, it was possible to identify, by cluster analysis, the distance education business models used by HEIs, as well as to group them according to the similarities in the adopted models. A taxonomic classification was created for each of the groups belonging to the nine building blocks of a distance education specific business model.

Strategically, a HEI can shape its business model according to the innumerable possibilities of combining the nine generic building blocks, with their respective sector-specific elements, and from this composition, it can become unique, which, once well-articulated, can be a source of competitive advantage, or differentiation in face of its competitors.

It was identified the possibility of forming 43 different business models from the cluster analysis performed. However, 2 business models stood out and were more frequent as far as they were equal in all building blocks in more than one institution: one being used by 4 institutions, and another by 2 .

Finally, the possibilities of shaping strategies and business models are extremely dynamic due to changes in the competitive environment and technology itself. Particularly in the undergraduate segment by means of distance education it is still expected continuous evolution and changes, given that the sector is in a phase of intense development and, apparently, far from a stage of maturity. In this sense, the research identified, in 2017, which are the main components and groups that characterize the business models in distance education in higher education in Brazil.

There is an important field of study on business models in Distance Education that is still little explored, and a research perspective would be, for example, the application of the typology identified in this research to the distance learning portfolio of educational institutions in order to evaluate eventual specificities of business models for each of the courses. Anyway, the generic business models along with the distance education sector specifics that were identified by the research, as well as the proposed taxonomy, can contribute not only to the better understanding of this crucial sector for social and economic development as for the development of other studies within distance education.

Acknowledgements: We thank Universidade Municipal de Sao Caetano do Sul and all private higher education institutions that offer distance undergraduation in Brazil that generously answered the data collection instrument (questionnaire) necessary for the research results. We thank the five interviewees who made possible a boost related to the issue business model at distance education in Brazil. And we thank COREAD - Ministerio da Educacao (MEC) that provided us with a systematized listing to our research field. 


\section{BIODATA and CONTACT ADDRESSES of AUTHORS}

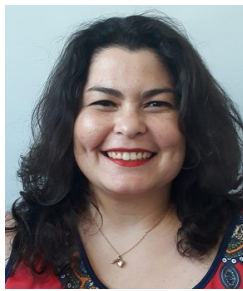

Dr. Lidiane BRITTO, holds a doctorate in Business Administration from the Municipal University of Sao Catenao do Sul, her mainly subject is based on e-learning business models. Actually is a distance learning teacher at the Cruzeiro do Sul University and also a professor in marketing and business strategy. He holds a masters degree in Communication at University Methodista of Sao Paulo and her major interests are: Digital and Internet Marketing, e- Learning and Business and Administration areas.

Lidiane BRITTO

Adress: Av. Dr. Ussiel Cirilo, 225 - Vila Jacui, Sao Paulo - SP, 08060-070. Brasil.

Phone: 5511 98371-9060

E-mail: lidiane_britto@yahoo.com.br

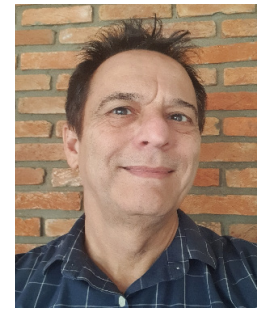

Dr. Sergio CRISPIM, is a professor of business strategy in the postgraduate program at USCS - Municipal University of Sao Caetano do Sul and associate professor at USP University of Sao Paulo, in Brazil. He has concentrated his research in the field of business models applied to various segments of activity, has guided more than forty dissertations and theses, and has published more than sixty articles in journals and academic congresses.

Sergio CRISPIM

Adress: Universidade Municipal de Sao Caetano do Sul, Rua Conceicao 321, Sao Caetano do Sul, SP, 09530-060, Brasil

Phone: $55114227-7811$

E-mail: scrispim@uol.com.br

\section{REFERENCES}

Associacao Brasileira de Educacao a Distancia (ABED). Disponivel em: <http://www.abed.org.br/site/pt/> Acesso em ago. 2015.

Brasil. Ministerio da Educacao. Decreto no. 5.622/05. Disponivel em: <http://www.mec.gov.br>. Acesso em: jan. 2015.

Britto, L. C. Modelos de negocio em educacao a distancia: um estudo de instituicoes de educacao superior privadas no Brasil. Tese (Doutorado). Programa de Pos-Graduacao em Administracao da Universidade Municipal de Sao Caetano do Sul, 2018.

Casadesus-Masanell, R.; Ricart, J. E. (2007). Competing through business models. IESE Business School. Working Paper. WP n.713.

Cassunde, F. R., \& Cassunde Junior, N. (2012). O estado do conhecimento sobre educacao a distancia (EAD) em administracao: por onde caminham os artigos?. Gestao \& Planejamento-G\& P, 13(2).

CENSO EAD.BR: Relatorio analitico da aprendizagem a distancia no Brasil 2016. ABED. Associacao Brasileira de Educacao a Distancia. Curitiba: InterSaberes, 2017.

Christensen, C. M. (2012). O dilema da inovacao: quando novas tecnologias levam empresas ao fracasso. Sao Paulo: Makron.

Christensen, C. M., Horn, M. B., \& Johnson, C. W. (2012). Inovacao na sala de aula: como a inovacao disruptiva muda a forma de aprender. Porto Alegre: Bookman Editora.

Christensen, C. M.; Eyring, H. J. (2014). A universidade inovadora. Mudando o DNA do ensino superior de fora para dentro. Porto Alegre: Bookman Editora.

Da Hora, Henrique Rego Monteiro; Monteiro, Gina Torres Rego; Arica, Jose. Confiabilidade em questionarios para qualidade: um estudo com o Coeficiente Alfa de Cronbach. Produto \& Producao, v. 11, n. 2, p. 85-103, 2010. 
Demil, B., \& Lecocq, X. (2010). Business model evolution: in search of dynamic consistency. Long range planning, 43(2-3), 227-246.

E-MEC. Instituicoes de Educacao Superior com credenciamento para oferta de EaD. Enviado por e-mail do COREAD- MEC, jan. 2016.

Aparecida Gouvea, M., Campi Prearo, L., \& do Carmo Romeiro, M. (2013). Avaliacao do emprego das tecnicas de analise de correspondencia e analise de conglomerados em teses e em dissertacoes de algumas instituicoes de ensino superior. Revista de Ciencias da Administracao, 15(35).

Hair, J. F., Black, W. C., Babin, B. J., Anderson, R. E., \& Tatham, R. L. (2009). Analise multivariada de dados. Bookman Editora.

Instituto Nacional de Estudos e Pesquisas Educacionais Anisio Teixeira (INEP). Ministerio da Educacao (MEC). Instrumentos. Ago. 2015. Disponivel em: <http://portal.inep.gov.br/instrumentos>. Acesso em nov. 2017.

Lambert, S. We need a "real" taxonomy of e-business models? School of Commerce Research Paper Series: 06-6. Flinders University. ISSN: 1441-3906. Disponivel em: https://www.researchgate.net/ publication/249812870_Do_We_Need_a_Real_Taxonomy_of_e-Business_Models>. Acesso em dez 2017.

Ministerio da Educacao (MEC)/ Instituto Nacional de Estudos e Pesquisas Educacionais Anisio Teixeira (INEP). Censo da Educacao Superior 2013. Disponivel em: < http://portal.inep.gov.br/web/ censo-da-educacao-superior> Acesso em: out. set. 2014.

Ministerio da Educacao (MEC). Portaria Normativa n.11, de 20 de junho de 2017. Disponivel em: <http:// portal.mec.gov.br/index.php?option=com_docman\&view=download \&alias=66431-portarianormativa-11-pdf\&category_slug=maio-2017-pdf\&Itemid=30192>. Acesso em dez 2017.

Ministerio da Educacao (MEC)/Secretaria de Articulacao com os Sistemas de Ensino (MEC/SASE), 2014. Planejando a proxima decada. Conhecendo as 20 metas do Plano Nacional de Educacao. Disponivel em: <http://pne.mec.gov.br/images/pdf/pne_conhecendo_20_metas.pdf >. Acesso em dez 2017.

Moore, Michael G; Kearsley, Greg. (2013). Educacao a distancia. Sistemas de aprendizagem on-line. 3ed. Sao Paulo: Cengage Learning.

Osterwalder, A., Pigneur, Y., \& Tucci, C. L. (2005). Clarifying business models: Origins, present, and future of the concept. Communications of the association for Information Systems, 16(1), 1.

Osterwalder, A., \& Pigneur, Y. (2011). Business model generation: inovacao em modelos de negocios. Alta Books Editora.

Prearo, L. C. (2008). O uso de tecnicas estatisticas multivariadas em dissertacoes e teses sobre o comportamento do consumidor: um estudo exploratorio (Doctoral dissertation, Universidade de Sao Paulo).

Rocha, M. W. G. (2015). Modelo de negocios: teoria e pratica: um estudo em empresas de tecnologia, (Doctoral dissertation, Universidade de Sao Paulo).

Sindicato das Mantenedores de Ensino Superior (SEMESP). Mapa do Ensino Superior no Brasil 2017. SEMESP, 2017.

Zott, C., \& Amit, R. (2008). The fit between product market strategy and business model: implications for firm performance. Strategic management journal, 29(1), 1-26.

Zott, C., Amit, R., \& Massa, L. (2011). The business model: recent developments and future research. Journal of management, 37(4), 1019-1042. 